\title{
A new species of the millipede genus Julus from the Rostov-on-Don Region, southern Russia (Diplopoda: Julida: Julidae)
}

\author{
Новый вид кивсяков рода Julus из Ростовской области \\ (юг России) (Diplopoda: Julida: Julidae)
}

\author{
Aleksandr P. Evsyukov \\ Александр П. Евсюков \\ Classical lyceum No.1, Balakireva Street 32, Rostov-on-Don 344004 Russia. E-mail: aevsukov@mail.ru \\ Классический лицей № 1, ул. Балакирева 32, Ростов-на-Дону 344004 Россия. \\ KEY WORDS: Diplopoda, Julidae, new species, Rostov-on-Don Region, southern Russia. \\ КЛЮЧЕВЫЕ СЛОВА: Diplopoda, Julidae, новый вид, Ростовская область, Южная Россия.
}

ABSTRACT. A new species of the millipede family Julidae, Julus alexandrae sp.n., is described from the Rostov-on-Don Region, southern Russia. It differs in gonopod characters, primarily the shape of the promere.

РЕЗЮМЕ. ОПисан новый вид кивсяков семейства Julidae, Julus alexandrae sp.n., из Ростовской области (Южная Россия). Он отличается признаками строения гоноподов, прежде всего, формой промера.

\section{Introduction}

Julus Linnaeus, 1758 is a rather small, but common and widespread genus of the diplopod family Julidae. Its distribution pattern is Palaearctic, ranging from Western Europe in the west, through the Caucasus, to southern Siberia and Mongolia in the east. Formally, Julus includes five subgenera [Lohmander, 1936]. However, because the number of species described in Julus has since doubled, while some of them fail to properly fit in this or that subgenus, a subgeneric classification has been abandoned [Mikhaljova, 2009, 2013].

At the moment, Julus contains 14 species (one of them with two subspecies), as follows:

J. azarovae Mikhaljova, 2009, from the Republic of Altai, Siberia, Russia [Mikhaljova, 2009].

J. colchicus Lohmander, 1936, from Russia, Abkhazia and Georgia, all within the NW and W Caucasus [e.g. Lohmander, 1936; Lang, 1959; Lokshina, Golovatch, 1979; Korobushkin et al., 2016; Chumachenko, 2016].

J. curvicornis Verhoeff, 1899, from Slovakia [Verhoeff, 1899].

J. ghilarovi brachydactylus Gulička, 1972, described from Siberia: the Republic of Altai [Gulička, 1963; Lokshina, Golovatch, 1979; Mikhaljova, 2004].
J. ghilarovi ghilarovi Gulička, 1963, from Siberia, Russia: the Kemerovo and Novosibirsk areas, the southern part of Krasnoyarsk Province, the Republic of Khakassia, the Republic of Altai [Gulička, 1963; Lokshina, Golovatch, 1979; Mikhaljova, 2004].

$J$. insolitus Mikhaljova, 2009, from the Republic of Altai, Siberia, Russia [Mikhaljova, 2009].

J. jedryczkowskii Golovatch, 1981, from North Ossetia, northern Caucasus, Russia [Golovatch, 1981].

J. kazakhus Mikhaljova, 2013, from eastern Kazakhstan and the Altai Mountains of Mongolia [Mikhaljova, 2013; Nefediev et al., 2015].

J. kubanus Verhoeff, 1921, from the northwestern Caucasus, Russia [Verhoeff, 1921; Lohmander, 1936; Lokshina, Golovatch, 1979].

J. lignaui Verhoeff, 1910, from the northwestern Caucasus, Russia [Verhoeff, 1910; Lokshina, Golovatch, 1979].

J. lindholmi Lohmander, 1936, from Abkhazia, western Caucasus [Lohmander, 1936; Lokshina, Golovatch, 1979].

J. scandinavius Latzel, 1884, reported from Great Britain, Ireland, Belgium, Luxembourg, the Netherlands, France, Germany, Switzerland, Czech Republic, Slovakia, Hungary, Denmark, Norway, Sweden and Poland, also introduced to North America (www. faunaeur.org) [Latzel, 1884; Lohmander, 1925; Schubart, 1934; Lokshina, Golovatch, 1979].

J. scanicus Lohmander, 1925, recorded from Germany, Austria, Czech Republic, Hungary, Slovakia, Denmark, Sweden, Latvia and Belarus (www.faunaeur. org) [Lohmander, 1925; Schubart, 1934; Lokshina, Golovatch, 1979].

J. subalpinus Lohmander, 1936, from the Krasnodar Province, northwestern Caucasus, Russia [Lohmander, 1936; Lokshina, Golovatch, 1979].

J. terrestris Linnaeus, 1758, the type-species, known from Germany, Austria, Croatia, Czech Republic, Hungary, Romania, Slovakia, Denmark, Sweden, Estonia, 

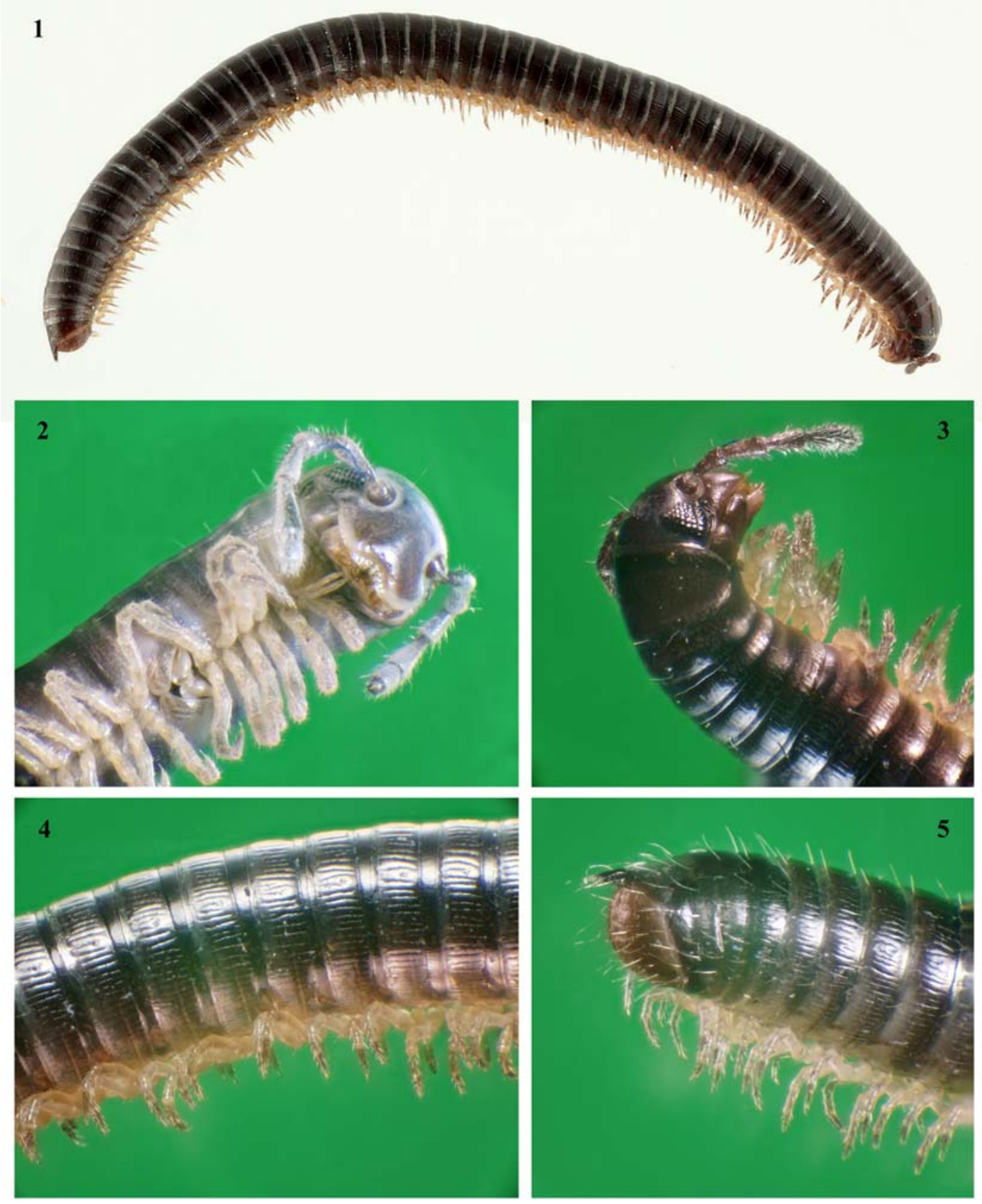

Figs 1-5. Julus alexandrae sp.n., O' paratype: 1 - habitus, lateral view (photo by Denis Kasatkin); 2 - anterior body portion, ventral view; 3 - anterior body portion, lateral view; 4 - midbody segments, lateral view; 5 - caudal body portion, lateral view. Pictures taken not to scale.

Рис. 1-5. Julus alexandrae sp.n., паратип О’: 1 - внешний вид сбоку (фото Дениса Касаткина); 2 - передняя часть тела, вид снизу; 3 - передняя часть тела, вид сбоку; 4 - среднетуловищные сегменты, вид сбоку; 5 - задняя часть тела, вид сбоку. Фотографии без масштаба.

Finland, Latvia, Lithuania, Belarus, Russia’s Kaliningrad Region, Poland and Ukraine (www.faunaeur.org) [Lohmander, 1925; Schubart, 1934; Lokshina, 1969; Lokshina, Golovatch, 1979; Chorniy, Golovatch, 1993].

Surprisingly, another, new species of Julus inhabits the Rostov-on-Don Region. Its description is given below.

\section{Material and methods}

The type material of the new species has been shared between the collections of the Zoological Museum of the Moscow State University (ZMUM) and the Museum of the Zoology Department of the Southern Federal University, Rostov-on-Don (RZM), both Russia. The 

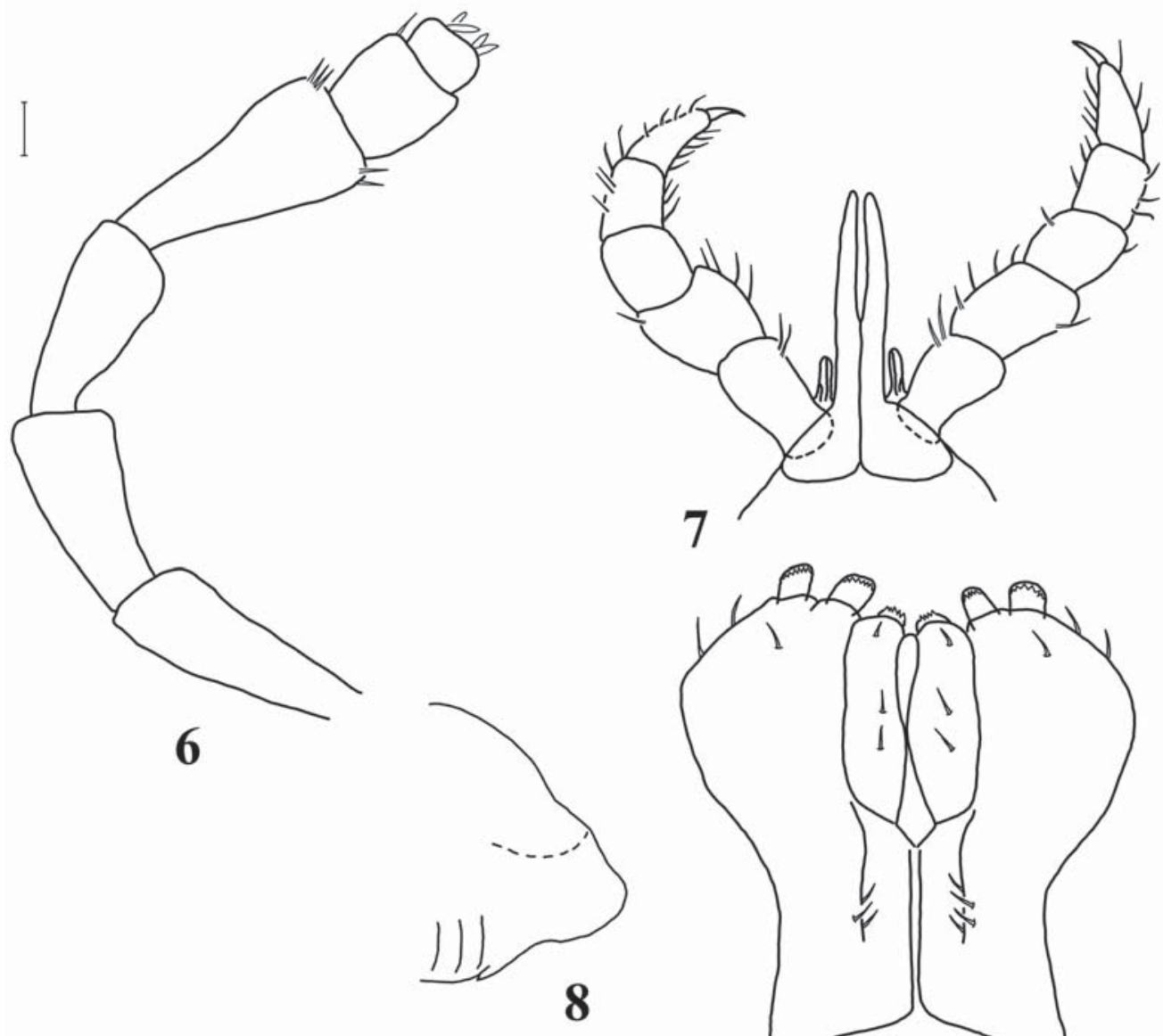

8

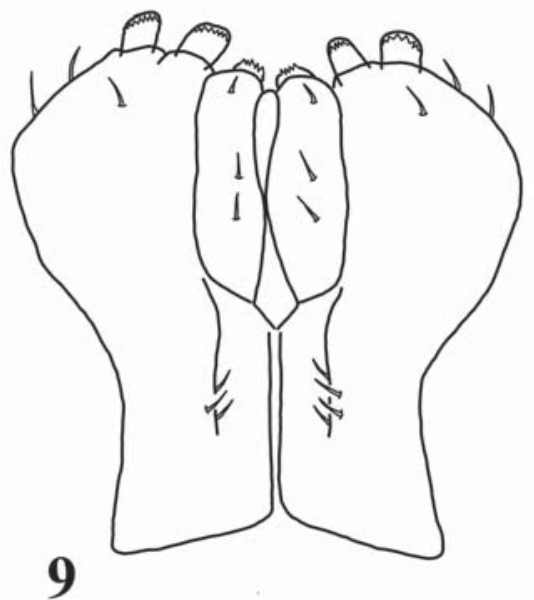

Figs 6-9. Julus alexandrae sp.n. $0^{7}$ paratype: 6 - antenna, lateral view; 7 - legs 2, caudal view; 8 - somite 7 , ventral edge; $9-$ gnathochilarium, ventral view. Scale bar $0.5 \mathrm{~mm}$.

Рис. 6-9. Julus alexandrae sp.n., паратип О': 6 - антенна, вид сбоку; 7 - ноги 2, вид сзади; 8 - сомите 7, нижний край; 9 гнатохиляриум, вид снизу. Масштаб 0,5 мм.

specimens are stored in 70-75\% ethanol. Some parts (gonopods, vulvae etc.) were dissected and mounted in temporary (glycerin) or permanent micropreparations (Canada balsam). Photographs was taken using a Lomo MSP microscope and a Sony A camera.

A "body segment formula" indicates the number of podous (including the gonopod-bearing segment) and apodous segments in an individual. This formula is $\mathrm{x}(-\mathrm{y})$ where $\mathrm{x}$ - sum of podous and apodous body segments, excluding telson, $\mathrm{y}$ - number of apodous body segments before telson.

\section{Taxonomic part}

Julus alexandrae sp.n.

Figs 1-14.

HOLOTYPE $\sigma^{7}$ (ZMUM $\left.\rho 3157\right)$, Russia, Rostov-on-Don Region, near Metchetinskaya, bank of Metchetka River, forest belt, leaf litter, 22.III.2015, leg. A. Evsyukov.

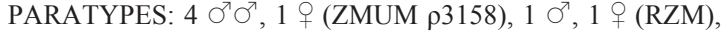
same data as holotype; $1 \sigma^{7}$ (ZMUM 03156 ), ca $120 \mathrm{~km} \mathrm{SW}$ of Rostov-on-Don, Leninskiy Forestry, IV.1982, leg. Z. Prishutova (a slide with antennae, gnathochilarium, $\sigma^{7}$ leg-pairs $1 \& 2$, and gonopods).

DIAGNOSIS. The new species seems to be especially similar to $J$. scandinavius Latzel, 1884. This concerns body coloration and the structure of the opisthomere. The main differences lie in the configuration of the promere, as well as in structure of $\sigma^{7}$ leg-pairs 1 and 2. Julus alexandrae sp.n. is also similar to J. scanicus Lohmander, 1925 in structure of $\sigma^{7}$ leg-pairs 1 and 2 . The differences likewise concern gonopod conformation.

NAME. To honour Alexandra, the author's daughter.

DESCRIPTION. Length 17-19 mm, width $1.4 \mathrm{~mm}$ $\left(\mathrm{O}^{7}\right)$, or length $19 \mathrm{~mm}$, width $1.6 \mathrm{~mm}(+)$. Body segment formula (excluding telson): $50(-1), 49(-1)$ or $52(-$ 1) $\left(\bigcirc^{7}\right) .51(-1), 50(-1)(+)$. Body dark brown, more intensely pigmented dorsally, lighter on ventral side; 


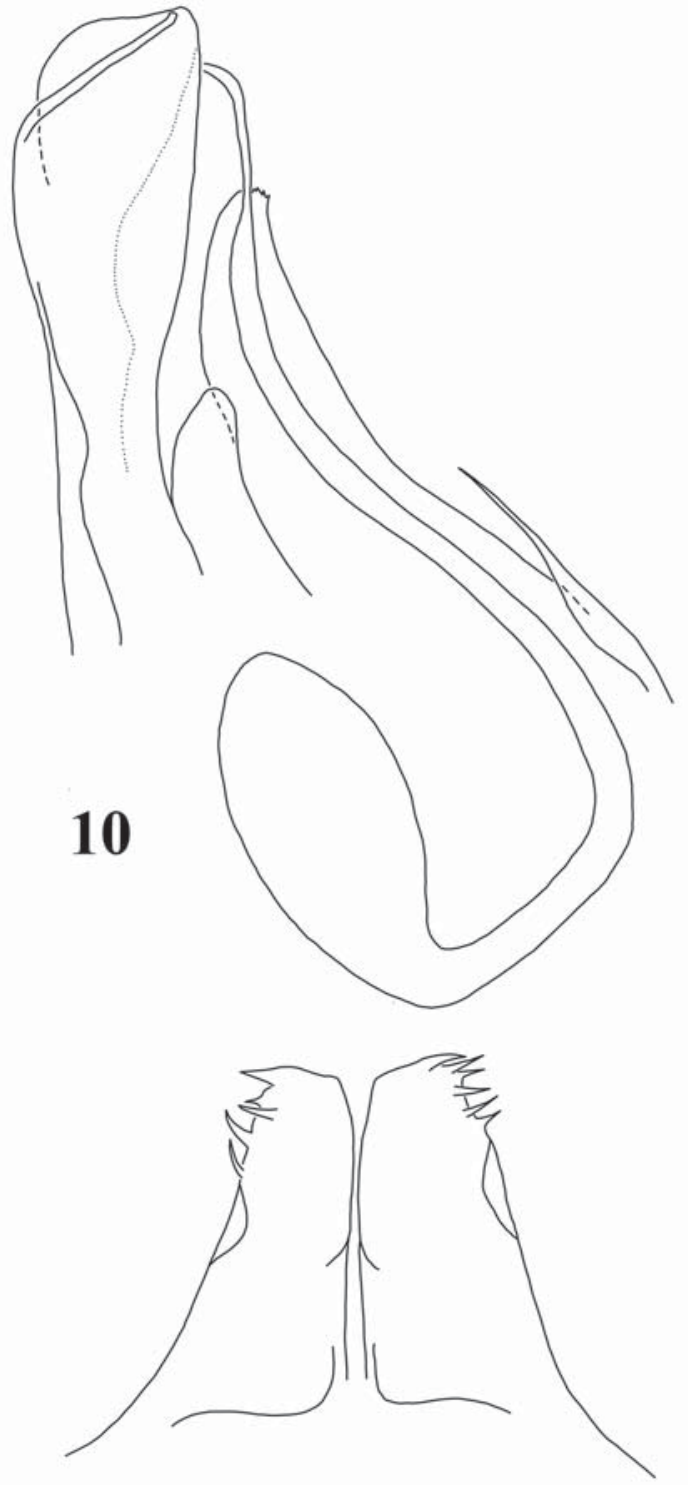

13

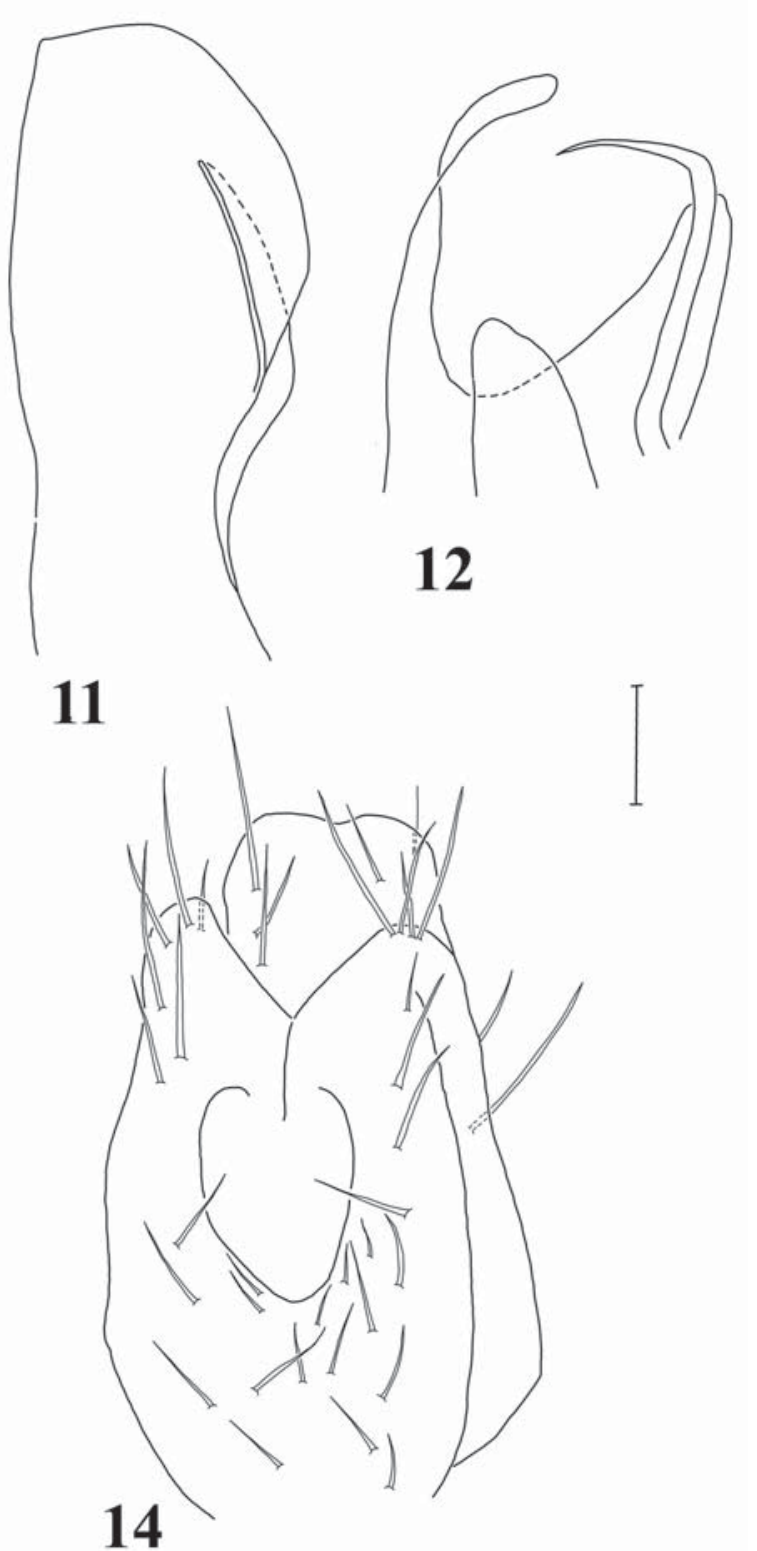

Figs 10-14. Julus alexandrae sp.n., $\sigma^{7}$ paratype: 10 - left gonopod, mesal view; 11 - promere, caudal view; 12 - end of opisthomere, mesal view; 13 - legs 1 , caudal view; + paratype: 14 - vulva, caudal view. Scale bar $0.2 \mathrm{~mm}$.

Рис. 10-14. Julus alexandrae sp.n., паратип $\sigma^{7}: 10$ - левый гонопод, вид изнутри; 11 - промер, вид сзади; 12 - конец опистомера, вид изнутри; 13 - ноги 1, вид сзади; паратип ㅇ: 14 - вульва, вид сзади. Масштаб 0,2 мм.

head, antennae and anal valves reddish brown; legs brownish yellow; eyes black $\left(O^{\top},{ }^{\circ}\right)$.

MALE. Eye patches subtriangular, each composed of ca 45 ocelli. Epicranial setae 1+1, supralabral setae $2+2$, labral setae $7+7$ or $8+8$. Genae unmodified. Antennae slender, in situ reaching until somite 4. Antennomere 5 with a distal corolla of 8 sensory bacilli (Fig. 6). Gnathochilarial stipial palps with small lamellae. Each lamella lingualis three setae. A pair of pronounced bolsters with a group of 3-4 setae at boundary between stipes and mentum (Fig. 9).
Body subcylindrical and slender (Fig. 1), darker and slenderer in $\sigma^{7}$ compared to + . Somites 6 and 7 stouter than others. Ventral edge of somite 7 within small curved lamellae forming a gonopodal opening (Fig. 8). Suture dividing pro- and metazona distinctly constricting both zonites. Ozopores small, lying behind suture without touching it. Metazonites with striae reaching the hind margin, 11-13 striae per about quarter of metazonital surface, i.e. between dorsal midline and ozopore (Fig. 4). A transverse row of sparse, thin, short setae at hind edge of metazonites, setae gradually grow- 
ing denser and somewhat longer towards telson. Telson with sparse long setae on epiproct and caudal projection (= tail). Tail carrying a small claw directed caudad. Anal valves convex, densely setose (Fig. 5).

Legs relatively long. Claws with a thin, long, setiform, ventral filament at base. Pregonopodal legs more incrassate than postgonopodal ones. Leg-pair 1 (Fig. 13) subtriangular with thick setae. Suture between basal and apical segments weakly expressed. Leg-pair 2 (Fig. 7) with two pairs of coxal processes. Lateral ones small and slender. Distal processes long, diverging from the middle. Penes short, not deeply bifurcated apically.

All three pieces of each gonopod (Fig. 10) condensed. Promere higher than opisthomere, flagella welldeveloped, thick and ribbon-shaped. Apex of flagellum projecting beyond opisthomere tip (Fig. 12). Distal part of opisthomere with small lamellae. Promere without telopodite remnant, narrowed basally, with a long, thin, spike-like outgrowth, laterally with a lamina, apically rounded and gently angular (Fig. 11). Mesomere simple, short, rounded at apex.

FEMALE. Suture between pro- and metazonites well-developed. Prozona with gentle irregular lines, metazonites densely striated. Ocelli ca $42-45$ per ocellarium. Epicranial setae $1+1$, supralabral setae $2+2$, labral setae $7+7$ or $8+8$. $11-12$ striae per about quarter of metazonital surface, i.e. between dorsal midline and ozopore. Size of all legs identical.

Vulvae (Fig. 14) densely setose, especially densely so in an M-shaped apical part.

REMARKS. It seems noteworthy that the presence of $J$. alexandrae sp.n. in the forested or typical steppes of the Rostov-on-Don Region quite considerably bridges the huge geographical gap observed between the Chernigov Region of Ukraine, whence the only reliable easternmost locality of $J$. terrestris has been documented [Lokshina, 1969], and several Julus species, largely high-montane, endemic to the northwestern and northern Caucasus [Lohmander, 1936; Golovatch, 1981]. No less remarkably, even though J. alexandrae sp.n. is geographically far closer to the Caucasus, the structure of its $\sigma^{7}$ legs 2, one of the main characters Lohmander [1936] based his subgeneric classification on, is unequivocally more similar to that of both purely European J. scandinavius and J. scanicus [Latzel, 1884; Lohmander, 1925; Schubart, 1934]. This implies European rather than Caucasian roots for the outlier J. alexandrae sp.n.

ACKNOWLEDGEMENTS. I am very grateful to Sergei Golovatch (Moscow, Russia) who helped me in preparing and publishing this note. I am also deeply obliged to Denis Kasatkin (Rostov-on-Don, Russia) who skillfully took the pictures.

\section{References}

Chornyi N.G., Golovatch S.I. 1993. [Millipedes (Diplopoda) of the plain territories of the Ukraine]. Kiev. 54 pp. [in Russian].

Chumachenko Y.A. 2016. [Millipede (Diplopoda) populations in a yew-boxwood grove of the Caucasian Nature Reserve, Russia] // Zoologicheskii zhurnal. Vol.95. No.4. P.406-416 [in Russian, with English summary].

Golovatch S.I. 1981. Some new forms of millipedes (Diplopoda) from the Caucasus // Annales Zoologici PAN. T.36. No.5. P.105-116.

Gulička J. 1963. [New millipedes (Diplopoda) from USSR. Part 1] // Zoologicheskii zhurnal. T.42. No.4. P.518-524 [in Russian]. Gulička J. 1972. [New millipedes (Diplopoda) from USSR. Part 2] // Zoologicheskii zhurnal. T.51. No.1. P.36-45 [in Russian].

Korobushkin D.I., Semenyuk I.I., Tuf I.H. 2016. An annotated checklist of the Chilopoda and Diplopoda (Myriapoda) of the Abrau Peninsula, northwestern Caucasus, Russia // Biodiversity Data Journal. Vol.4. P.1-33, e7308.

Lang J. 1959. [To the knowledge of millipedes (Diplopoda) of the USSR territory] // Zoologicheskii zhurnal. T.38. No.12. P.17901796 [in Russian].

Latzel R. 1884. Die Myriopoden der Österreichisch-Ungarischen Monarchie, 2. Hälfte. A. Hölder, Wien. 414 S.

Lohmander H. 1925. Sveriges Diplopoder// Göteborgs Kungl. Vetenskaps- och Vitterhets-Samhälles Handlingar. Bd.4. No.2. S.1-115.

Lohmander H. 1936. Über die Diplopoden des Kaukasusgebietes // Göteborgs Kungl. Vetenskaps- och Vitterhets-Samhälles Handlingar. Ser. 5B. Bd.5. No.1. S.1-196.

Lokshina I.E. 1969. [Identification book of the millipedes (Diplopoda) in the plain parts of the USSR European territory]. Moscow: Nauka Publ. 78 pp. [in Russian].

Lokshina I.E., Golovatch S.I. 1979. Diplopoda of the USSR fauna // Pedobiologia. Bd.19. P.381-389.

Mikhaljova E.V. 2004. The millipedes (Diplopoda) of the Asian part of Russia. Sofia-Moscow: Pensoft. 292 pp.

Mikhaljova E.V. 2009. New species of the family Julidae Leach 1814 from Altai, Russia (Diplopoda, Julida) // Zootaxa. Vol.2235. P.59-68.

Mikhaljova E.V. 2013. New data on the millipede fauna (Diplopoda) of Altai, Russia // Far Eastern Entomologist. No.265. P.110.

Nefediev P.S., Nefedieva Ju.S., Jankowski K. 2015. The first record of a julid millipede (Diplopoda: Julida: Julidae) from the Altai Mountains of Mongolia // Invertebrate Zoology. Vol.12. No.2. P. $213-214$.

Schubart O. 1934. Tausendfüßler oder Myriapoda. I: Diplopoda // Dahl F. (Hrsg.). Die Tierwelt Deutschlands. Teil 28. 318 S.

Verhoeff C. 1899. Beiträge zur Kenntniss paläarktischer Myriopoden. IX. Aufsatz: Zur Systematik, Phylogenie und vergleichenden Morphologie der Juliden und über einige andere Diplopoden // Archiv für Naturgeschichte. Bd.65. H.1/3. S.183221.

Responsible editor S.I. Golovatch 